\title{
A review of therapeutic potentials of sweet potato: Pharmacological activities and influence of the cultivar
}

\author{
Taiwo Betty Ayeleso ${ }^{1}$, Khosi Ramachela ${ }^{2}$ and Emmanuel Mukwevho ${ }^{1 *}$ \\ ${ }^{1}$ Department of Biological Sciences, North-West University, Private Bag X2046, Mmabatho, ${ }^{2}$ Department of Crop Science, \\ North-West University, Private Bag X2046, Mmabatho 2735, South Africa \\ ${ }^{\star}$ For correspondence: Email: Emmanuel.mukwevho@nwu.ac.za; Tel: +27183892854
}

\begin{abstract}
Sweet potato (Ipomoea batatas) is a global food crop, now being recognized as a functional food due to several of its nutraceutical components. Several experimental studies have reported that sweet potato can generally be beneficial in the prevention or treatment of chronic diseases through its antioxidant, anti-inflammatory, immunomodulatory, anticancer/antitumour, antimicrobial and antiulcer activities. Studies on the haematinic effect of potato leaves and their ability to enhance some haemotological parameters are reviewed in this paper. Furthermore, the review provides an overview of the significance and influence of cultivar on the composition and pharmacological activities of sweet potato. Sweet potato contains a lot of beneficial phytochemicals, some of which are peculiar to certain varieties. There is, therefore, a need for the continuous evaluation and selection of cultivars with the appropriate phytochemical composition and bioactivities to be able to fully explore the medicinal value of sweet potato. Studies aimed at the isolation, characterization and toxicological evaluation of its bioactive compounds may help to strengthen and confirm the possible role of sweet potato as a health promoting food and an alternative remedy for chronic diseases. This review highlights the pharmacological reports on different forms of sweet potato and their potential medicinal values.
\end{abstract}

Keywords: Sweet potato, Cultivar influence, Chronic diseases, Ipomoea batatas, Diabetes, Anticancer, Haematological effect

Tropical Journal of Pharmaceutical Research is indexed by Science Citation Index (SciSearch), Scopus, International Pharmaceutical Abstract, Chemical Abstracts, Embase, Index Copernicus, EBSCO, African Index Medicus, JournalSeek, Journal Citation Reports/Science Edition, Directory of Open Access Journals (DOAJ), African Journal Online, Bioline International, Open-J-Gate and Pharmacy Abstracts

\section{INTRODUCTION}

Sweet potato, Ipomoea batatas (L.) Lam, is a perennial crop which belongs to the morning glory family or Convolvulaceae [1]. It is a popular staple food of the tropical and subtropical areas with a nutritional benefit evidenced by increase in its cultivation and consumption [2]. Sweet potato is mostly harvested for its tubers. However, the leaves are also sometimes consumed as an alternative to other leafy vegetables. It is the sixth most important food crop in the world and it contains phytochemicals, which are important for human health [3,4]. Other than their nutritional benefits such as a rich source of dietary fibre, antioxidants, vitamins, and minerals, sweet potato root tubers also contain no saturated fats or cholesterol. Islam, 2014 reported that sweet potato leaves contain more polyphenols than any other commercial vegetables such as spinach, cabbage, and lettuce. He stated that, the leaves of sweet potato contain at least 15 anthocyanins and 6 polyphenolic compounds [3].

Several reports have indicated that the phytochemicals in sweet potato possess multifaceted actions, including anti-oxidant, antimutagenic, anti-inflammatory, antimicrobial and 
anti-carcinogenesis and thus are important for several health-promoting functions in humans [5]. Different varieties of sweet potato are grown worldwide and these are generally characterized by the different flesh colours with varying phytochemical compositions. Different varieties of a plant may inherently differ in their nutritional values and in the bioactivities of phytochemicals present in the plants [6,7]. The nutritional value and medicinal potentials of sweet potato are gaining the attention of so many research groups as the quest for natural remedies from plants as well as the understanding between diet and health increases worldwide. Sweet potato plant alongside being primarily a food resource may as well be exploited for its medicinal properties due to its high nutritive and therapeutic properties.

\section{ORIGIN, DISTRIBUTION AND PRODUCTION OF SWEET POTATO}

Sweet potato, although native to tropical regions in America is an important and global food crop which is cultivated in more than 100 countries, with the primary or main commercial producers in China, Indonesia, Vietnam, Japan India, Tanzania and Uganda [8]. Limpopo, Mpumalanga (Nelspruit), KwaZulu-Natal and Western Cape provinces are the major production areas in South Africa [9]. Sweet potato is mainly grown in developing countries which account for a $95 \%$ of the global output. China accounts for about $65 \%$ of the world's sweet potato. In most parts of Africa, production of sweet potato is often done on a small or subsistence level. Nonetheless, there are high productions in Lake Victoria area in East Africa (Rwanda, Uganda, Burundi and Congo), Nigeria, Ghana and Madagascar [10].

Sweet potato yields maximum and better quality roots on a well-drained, sandy or silt loam soil. It requires both warm days and nights for optimum growth and root development [11]. Storage root development of sweet potato also depends on good soil aeration. Good soil aeration can be achieved by good field choice and bedding before transplantation. It is very sensitive to alkaline and saline conditions which influence growth. Soil pH between 5.6 and 6.6 is very good for the production of sweet potato. [12].

\section{NUTRITIONAL VALUE OF SWEET POTATO}

Sweet potatoes are rich in complex carbohydrates, dietary fiber and beta carotene (a precursor of vitamin A), vitamin B6, and vitamin $C$ (Table 1). In addition to this, various parts of the crop have been reported to also contain mineral nutrients such as zinc, potassium, sodium, manganese, calcium, magnesium and iron [13]. According to Food and Agricultural Organisation (FAO) [14], sweet potato leaves and shoots are good sources of vitamins $A, C$ and B2 (riboflavin), and lutein. Orange sweet potato varieties have higher beta carotene content than those with light colored flesh and their increased cultivation is being encouraged in Africa where Vitamin A deficiency is a challenging health issue. On the other hand, purple-fleshed sweet potato has been reported to contain anthocyanins, which possess antioxidant activities [15]. Although the protein content of sweet potato is low ( 2\%) as in most tropical root and tuber crops, sweet potato still contains more protein than cassava and plantain [13]. The leaves have relatively high protein content (25-30 $\%$ of dry matter) compared to other leafy vegetables. The leaves also have higher levels of polyphenols than any other commercial vegetables [3]. Polyphenols have a strong role in the prevention of degenerative diseases especially cancer and cardiovascular diseases through their antioxidant activities [16].

Table 1: Nutritional value of sweet potato [17]

\begin{tabular}{|c|c|c|}
\hline \multirow[t]{2}{*}{ Proximate parameter } & \multicolumn{2}{|c|}{ Nutritional value per $\mathbf{1 0 0 ~} \mathrm{g}$} \\
\hline & Root tuber & Leaf \\
\hline Water & 77.28 & 86.81 \\
\hline Enerqy (kcal) & 86 & 42 \\
\hline Carbohydrates $(g)$ & 20.12 & 8.82 \\
\hline Protein $(g)$ & 1.57 & 2.49 \\
\hline Total fiber $(g)$ & 3 & 5.3 \\
\hline Total lipid (g) & 0.05 & 0.51 \\
\hline \multicolumn{3}{|l|}{ Vitamins } \\
\hline Vitamin A (IU) & 14187 & 3778 \\
\hline Thiamine (mg) & 0.078 & 0.156 \\
\hline Riboflavin (mg) & 0.061 & 0.345 \\
\hline $\operatorname{Niacin}(\mathrm{mg})$ & 0.557 & 1.130 \\
\hline Vitamin B6 (mg) & 0.209 & 0.190 \\
\hline Folate (B9) $(\mu \mathrm{g})$ & 11 & 1 \\
\hline Vitamin C (mg) & 2.4 & 11 \\
\hline Vitamin $\mathrm{K}(\mu \mathrm{g})$ & 1.8 & 302.02 \\
\hline \multicolumn{3}{|l|}{ Minerals } \\
\hline Calcium (mg) & 30 & 78 \\
\hline Iron (mg) & 0.61 & 0.97 \\
\hline Magnesium (mg) & 25 & 70 \\
\hline Phosphorus (mg) & 47 & 81 \\
\hline Potassium (mg) & 337 & 508 \\
\hline Sodium (mg) & 55 & 6 \\
\hline \multicolumn{3}{|l|}{ Lipids } \\
\hline $\begin{array}{l}\text { Fatty acids, total saturated } \\
\text { (g) }\end{array}$ & 0.018 & 0.111 \\
\hline $\begin{array}{l}\text { Fatty acids, total } \\
\text { monounsaturated }(\mathrm{g})\end{array}$ & 0.001 & 0.020 \\
\hline $\begin{array}{l}\text { Fatty acids, total } \\
\text { polyunsaturated }(\mathrm{g})\end{array}$ & 0.014 & 0.228 \\
\hline
\end{tabular}




\section{VARIETIES/ CULTIVARS OF SWEET POTATO}

Today, there are several cultivars of sweet potato known and cultivated around the world. These cultivars come in different colors, shapes, sizes and also vary in taste and texture. There are three major categories of sweet potato cultivars. The staple types which are white, red/purple skinned with white/cream flesh and are characterized by their high starch content. There are also the desert types which are orange skinned, orange fleshed and are characterized by their high beta carotene content [9]. Different cultivars of sweet potato are also characterized by their colours, width, thickness and shapes of the leaves [18]. In Southern Africa, formal sweet potato breeding was initiated in 1952 [19] and the most commercially successful has been Blesbok, a purple-skinned high yielding cultivar with low dry matter content [20].

There are several cultivated varieties of sweet potato in the United States but one of the leading and the most widely cultivated is the carrot coloured and orange-silver skinned cultivar known as Centennial. Beauregard and Jewel are also dominant varieties of sweet potato that is being popularly consumed in the United States [21]. In China, where sweet potato breeding is now aimed at improved nutrition in animal feed and high starch content, a large number of new cultivars are emerging each year. 'Xushu 18" which was bred for high resistance against sweet potato root rot disease caused by Fusarium solani still remains the most cultivated variety in China [22]. In sub-Saharan Africa, sweet potato is a major food crop now being bred for improved nutrition. An example is the increased production of orange cultivars to combat vitamin A deficiency [23]. Globally, several improved cultivars of sweet potato have been developed by collection of the best local farmer varieties as well as the introduction of best cultivars from other parts of the world. As in all other plants, objective of breeding in sweet potato is mostly for improved nutritional benefit, high yield, long storability and, resistance to pest and diseases [24].

\section{PYTOCHEMICALS IN SWEET POTATO}

The major phytochemicals that are generally present in sweet potato are flavonoids, terpenoids, tannins, saponins, glycosides, alkaloids, steroids and phenolic acids. These constituents may vary with varieties depending on flesh and skin colours. Orange varieties are particularly rich in beta-carotene, while purple sweet potato contains higher anthocyanin content than other varieties of sweet potato [25].
Beta carotene is a terpenoid with a strongly colored red-orange pigment abundant in plants and fruits. Anthocyanins are members of the flavonoid group of phytochemicals responsible for the red, purple and blue pigments in many fruit and vegetables [26]. The antioxidant activities of sweet potato have mostly been attributed to their anthocyanin and beta-carotene contents. Structures of common phytochemicals in sweet potato are shown in Fig 1. Peonidin and cyanidin are examples of anthocyanins present in purple sweet potato. In a metabolite profiling study done by Park and colleagues [27], peonidin and cyanidin were only detected in purple fleshed sweet potato but not in the white and orange varieties. Luteolin, a flavonoid was found in orange and purple varieties but was absent in the white ones.

Phenolic acids such as chlorogenic, isochlorogenic, caffeic, cinammic, and hydroxycinammic acids are also generally present in sweet potato. Phenolic acids have been associated with color, sensory qualities, nutritional value as well as antioxidant properties of foods [28]. They are more abundant in purple fleshed sweet potato than in the other colors varieties [27]. Other important chemical compositions of sweet potato include starch, protein, vitamins, minerals and dietary fibre. The dietary fibre; hemicellulose and cellulose are also vital components of sweet potato due to its protectant abilities against colon cancers and vascular diseases [13]. Vitamin A is abundant in orange fleshed sweet potato and hence an appropriate food source to address vitamin A deficiency [29]. High content of vitamin B6 in the root tubers help in reducing the blood levels of homocysteine, an amino acid which has been implicated as a risk factor in cardiovascular diseases [30].

\section{MEDICINAL POTENTIALS OF SWEET POTATO}

Many studies have reported different medicinal potentials of sweet potato. These properties have been attributed to either a single or combined effect of the phytochemicals present in the plant. In traditional medicine, sweet potato has been used to treat many diseases such as oral infections, inflammatory diseases [31] and also in the management of diabetic conditions [32]. In recent times, pharmacological potential of sweet potato has been investigated and demonstrated by different in vitro, animal models and a few human studies. 


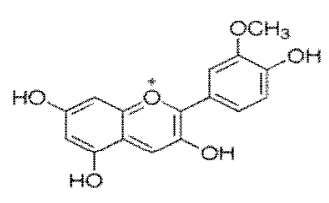

Peomidin

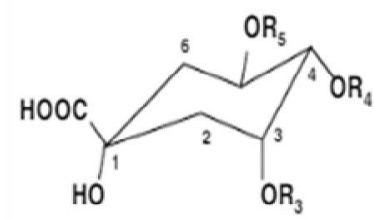

Quinic acid

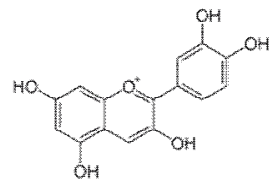

Cyanidin<smiles>Cc1ccc(C2=CC(=O)C3C(C)CC(O)CC3O2)cc1O</smiles>

Luteolin<smiles>O=C(O)/C=C/c1ccc(O)c(O)c1</smiles>

Caffeic acid<smiles>O=C(OC1CCC(O)C(O)C1)OC1CC(O)C(O)C(O)C1O</smiles>

Chlorogenic acid

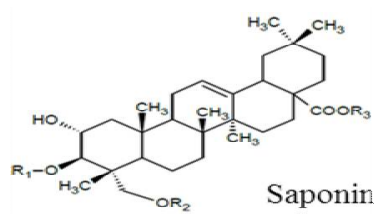

Figure 1: Some common phytochemicals in sweet Potato

\section{Anti-oxidant activities}

Phytochemicals such as flavonoids and related phenolic compounds which are generally present in sweet potatoes have been reported to have multiple biological effects, such as antioxidant activity. Purple-fleshed variety has been reported to contain anthocyanins, which possess antioxidant activity [15]. Antioxidants act as scavengers of free radicals reactive oxygen species inside the cell [33]. Many evidences suggest that degenerative diseases such as cancer, asthma, diabetes, senile dementia and eye disease have their origin in deleterious free radical reactions [34].

The free radical scavenging activity of extracts from the leaves of 8 cultivars of sweet potato was confirmed using 1, 1-diphenyl-2-picrylhydrazyl (DPPH) assay. The antioxidant activity of the leaves' extract correlated with the total polyphenol content [35]. Fidrianny et al [36] concluded from their study that n-hexane, ethylacetate and ethanol extracts of leaves from different cultivars of sweet potato showed free radicals scavenging activity. In the root tubers of sweet potato, antioxidant activity has also been demonstrated in different cultivars $[37,38]$. A stronger antioxidant activity was reported in the peels of white and purple varieties when compared to the flesh samples [39], showing that the skin of sweet potato root tubers are also rich source of anti-oxidative phytochemicals.

\section{Anti-diabetic effect}

There are studies that have suggested that sweet potato has the potential of lowering the blood glucose level. In some animal and human studies, different forms of sweet potato have been reported to help in maintaining blood sugar levels and lowering insulin resistance. 'Caiapo' is a dietary supplement and a crude extract of white skinned sweet potato which has been sold and consumed for a long time in Japan as a remedy for diabetes [40]. 'White star' a sweet potato cultivar indigenous to Pakistan and 'Beauregard' which is indigenous to the United States lowers glucose blood level in diabetic patients [41]. The leaf extract of sweet potato reduces significantly the level of blood glucose and hepatic enzymes activities in Alloxan-induced diabetic rats [42]. This agrees with the result of a recent study by $\mathrm{Pal}$ et a/ who reported that the aqueous extract of the leaves of sweet potato shows significant improvement in the blood glucose profile of diabetic rats [43].

The blood glucose lowering effect of white skinned sweet potato in type 2 diabetic patients has been linked to an increase in blood levels of adiponectin; an adipocyte hormone that serves as an important modifier of insulin metabolism [44]. Patients with poorly-regulated insulin metabolism and insulin insensitivity tend to have lower levels of adiponectin, and individuals with healthier insulin metabolism tend to have higher levels [45]. Generally, the anti-diabetic property of sweet potato has been attributed to its phytochemical content, Zhao et al [46] isolated flavone from the leaves of sweet potato and evaluated its effects on different markers of diabetes, there was a significant decrease in the 
fasting plasma insulin and blood glucose level and significant increase in the insulin sensitive index in non-insulin dependent diabetic rats.

\section{Anti-cancer potential}

Extracts from different parts of sweet potato have also been reported to exhibit anticancer and antitumor properties. Sweet potato extract inhibits proliferation and induces apoptosis in prostate cancer cells in vivo and in vitro [47], this anticancer activity was attributed to the high polyphenol content of the extract. Similarly in a very recent study, purple fleshed sweet potato extract was found to have inhibitory effect on the growth of MCF-7 (breast cancer) and SNU-1 (gastric cancer) cancer cell lines [48]. The therapeutic potential of purple fleshed sweet potato has mostly been attributed to its high anthocyanin content. Anthocyanins or anthocyanin-rich extracts have displayed inhibitory effect on cancer cell growth in various cancer cells [49]. A group of researchers also reported that purified protein from the storage root of sweet potato promotes dose- and timedependent inhibition of human colorectal cancer SW480 cell proliferation, migration and invasion [50].

\section{Anti-ulcer potential}

Ulcer is characterized by the shedding of inflamed tissue from the skin or mucous membrane [51]. Methanol extract of sweet potato roots showed gastroprotective activity against aspirin-induced ulcer in Wistar rats in a dose dependent manner [52]. The flour of sweet potato roots potentially prevented ethanolinduced gastric ulceration by suppressing edema formation and partly protecting gastric mucosa wrinkles [53]. In another in vivo study, ethanolic extract of sweet potato roots shows antacid-like action against a pylorus ligation and cold restraint stress induced ulcer in animal models [54].

\section{Effect on cardiovascular system}

The oxidation of low-density lipoprotein can cause complications which can result into atherosclerosis leading to cardiovascular disease [55]. Sweet potato leaf extract was able to suppress low density lipoprotein oxidation in vitro and in human subjects, this suppression was attributed to the antioxidant activity of phytochemicals present in the leaves [35]. Anthocyanin which is an abundant phytochemical in purple fleshed sweet potato has been reported to be able to reduce the risk of coronary disease [55].

\section{Effect on immune system}

Sweet potato extracts have also been reported to have modulatory effects on the immune system and health. Ethyl acetate fractions of bioactives extracted from two different cultivars of sweet potato exhibited immunomodulatory activities in a cultivar dependent manner in mice splenocytes [56]. Hanieh et al [57] reported that dietary supplementation of purple sweet potato improved immune response after immunization in chickens. Similarly, the consumption of purple sweet potato leaves was able to modulate Tlymphocyte functions, lytic activity of natural killer cell and antibody production in a study involving 16 healthy human adults [58]. Reports of immunomodulatory studies on sweet potato are mostly on purple skinned potato cultivars.

It has been postulated that extracts from purple sweet potato improve immune dysfunction possibly by modulating antioxidant defense systems [59]. A dietary supplement with purple sweet potato extract increased the activity of the antioxidant enzymes, superoxide dismutase and glutathione peroxidase in in LP-BM5 murine leukemia virus-induced murine acquired immune deficiency syndrome [59]. The cooked leaves of sweet potato leaves also showed immunomodulatory effect when consumed by basketball players during a training period. The plasma concentration of polyphenols in the players increased significantly during this period coupled with a significant increase in the cytotoxic activity of nature killer cells, and secretion of interferon (IFN)-y [60].

\section{Antimicrobial effects}

Although reports of the antimicrobial activities of sweet potato root are limited, antimicrobial activity of the leaves has been reported in a number of studies. Adsul et al [61] reported that acetone and ethanol extracts of sweet potato leaves showed antimicrobial activity against Salmonella typhimurium and Pseudomonas aeruginosa respectively, while $\mathrm{n}$-hexane and ethyl acetate extracts do not show any antimicrobial activity against the said strains. Mbaeyi-nwa and Emejulu tested the antimicrobial activity of peptone, water and ethanol extracts of sweet potato leaves against E. coli, S. typhi, S. aureus, $A$. niger, Penicillium spp., $P$. aeroginosa and $K$. pneumonia. They reported that the water extract exhibited high antimicrobial activity by inhibiting the growth of all the organisms except E. coli and Penicillium spp at different concentrations of the extracts [62]. Dietary fibre from the root of sweet potato also showed inhibitory effect against the growth of food-borne 
bacteria [63] while antimicrobial film made with sweet potato starch incorporated with varying levels of potassium sorbate or chitosan exhibited inhibitory effects on E. coli [64].

\section{Anti-inflammatory potential}

The potential of purple sweet potato extract to inhibit inflammatory brain diseases by suppressing lipopolysacharide (LPS) induced inflammatory responses have been demonstrated by a number of studies, pretreatment with purple sweet potato extract was able to inhibit the production of proinflammatory molecules in LPS activated BV-2 microglial cells [65]. Purple sweet potato colour extract was able to suppress the proinflammatory molecules by inhibition of phosphorylated extracellular signal-regulated kinase (ERK), phosphorylated c-Jun nterminal kinase (JNK) expression and nuclear factor kappa B (NF-kB) activation in a group of LPS- stimulated mice [66].

\section{Haematological effects}

Sweet potato leaf is used in traditional medicine as a remedy for anaemia due to it haematinic effects [67]. In a recent study by Montejo et al, sweet potato leaves powder diet increased the packed cell volume, haemoglobin levels and red blood cells in mice [68]. Similarly, an earlier study reported a significant increase in packed cell volume, white blood cells and platelets of rabbit fed with sweet potato extract [67].

\section{VARIATION IN CHEMICAL COMPOSITION AND BIOACTIVITY OF SWEET POTATO CULTIVARS}

The level and activity phytochemicals in plants have been confirmed by various studies to often vary among cultivars of the same species. Different cultivars of the same plant species adapt very differently to their environment, even though they are native of the same environment. These variations in adaptation may consequently affect the nutritional status and also the level of phytochemicals of closely related genotypes of a species [69]. For instance, a number of experiments have shown that although most pomegranate varieties have similar composition of phytochemicals, the level or amount of the phytochemicals may depend on the cultivar [70, 71]. Also in guava, the antioxidant activity and phytochemical composition of $P$. guajava vary significantly depending on to cultivar and pulp color [6].
In sweet potato, variation in phytochemical composition and bioactivities in selected cultivars have also been reported by a number of studies $[41,15,38]$. The caffeic acid content differs significantly across 24 cultivars of sweet potato [72] while the total and individual phenolic acid among 6 sweet potato cultivars investigated by Padda and Picha [73] vary significantly across the cultivars. A recent comparative study by Shekar et al of orange and white fleshed sweet potato revealed increased levels of protein, flavonoids, anthocyanins and carotenoids in orange fleshed sweet potato than in white fleshed sweet potato [7]. They also reported that although differential proteomic analysis indicated several spots common to both cultivars, certain spots were peculiar to either the orange fleshed or the white fleshed sweet potato.

Similarly in the analysis of 4 different (purple, red, yellow and white) sweet potato cultivars, the highest antioxidant activity was recorded in the purple variety while other parameters investigated vary significantly across the different cultivars [38]. Studies have indicated that the antioxidant activity in purple fleshed sweet potato is relatively higher than other varieties of sweet potato $[73,74$,$] . Different cultivars of sweet potato$ with varying flesh colors also exhibited varying antimicrobial activities. 'White star' a Pakistani cultivar of sweet potato showed better antidiabetic potential than 'Beuragard' a US cultivar as shown from the postprandial glucose level and insulin response in diabetic patients [41]. Although most reports of the anti-hyperglycemic potential of sweet potato leaves do not specify the variety of the plant used, the antidiabetic activities of sweet potato tuber has mostly been associated with the white skinned variety $[75,40]$. In general, the orange varieties have high betacarotene content and the ability to combat vitamin A deficiency. The reports of antiinflammatory and immunomodulatory activities are mostly associated with the purple fleshed sweet potato variety (Table 2). As in other plants, proper analysis and selection of cultivars with the optimal and desired phytochemical compositions would remain crucial to exploring the medicinal/therapeutic potential of sweet potato.

\section{WHAT NEXT?}

A major challenge in the investigation of medicinal plants is the need to identify the chemical nature of bioactive compounds responsible for the overall biological activity exhibited by the plant [79]. Even though some studies have made use of specific bio-actives such as anthocyanin from sweet potato, most 
Table 2: Reports of pharmacological activities of sweet potato

\begin{tabular}{|c|c|c|c|c|}
\hline Investigation & $\begin{array}{l}\text { Cultivar colour } \\
\text { description }\end{array}$ & $\begin{array}{l}\text { Form of sweet } \\
\text { potato used }\end{array}$ & $\begin{array}{c}\text { Type of } \\
\text { study/subject }\end{array}$ & Results \\
\hline $\begin{array}{l}\text { Antidiabetic activity of } \\
\text { flavone extracted from the } \\
\text { leaves leaf[46] }\end{array}$ & $\mathrm{N} / \mathrm{S}$ & $\begin{array}{l}\text { Flavone extracted } \\
\text { from the leaf }\end{array}$ & $\begin{array}{l}\text { Non-insulin } \\
\text { dependent } \\
\text { diabetic rats }\end{array}$ & $\begin{array}{l}\text { Modulate the metabolism } \\
\text { and lowers blood glucose } \\
\text { level }\end{array}$ \\
\hline Antioxidant activities[16] & $\begin{array}{l}\text { Cream, white, } \\
\text { orange ,yellow } \\
\text { and purple }\end{array}$ & $\begin{array}{l}\text { Hydrophilic and } \\
\text { lipophilic fractions } \\
\text { of Hexane extract } \\
\text { of root tubers }\end{array}$ & In vitro assays & $\begin{array}{l}\text { Highest antioxidant } \\
\text { activity recorded in purple } \\
\text { fleshed and the lowest in } \\
\text { white fleshed varieties }\end{array}$ \\
\hline $\begin{array}{l}\text { Immunomodulatory } \\
\text { effects } \\
\text { after immunization in } \\
\text { chickens [57] }\end{array}$ & Purple & $\begin{array}{l}\text { Sweet potato } \\
\text { powder as dietary } \\
\text { supplementation }\end{array}$ & Chickens & $\begin{array}{l}\text { Immune response of } \\
\text { chicken after } \\
\text { immunization was } \\
\text { improved }\end{array}$ \\
\hline $\begin{array}{l}\text { Wound healing and } \\
\text { antiulcer properties[51] }\end{array}$ & White & Tuber flour & Wistar rats & $\begin{array}{c}\text { Shows wound healing } \\
\text { potential }\end{array}$ \\
\hline $\begin{array}{l}\text { Effects on level of blood } \\
\text { glucose and } \\
\text { Hepatic Enzymes [42] }\end{array}$ & $\mathrm{N} / \mathrm{S}$ & $\begin{array}{l}\text { Aqueous extract } \\
\text { of leaf powder }\end{array}$ & Mice & $\begin{array}{l}\text { Lowers blood glucose, } \\
\text { reduces the activity of } \\
\text { hepatic enzymes }\end{array}$ \\
\hline $\begin{array}{l}\text { Antihyperglycemic and } \\
\text { antidyslipidemic potential } \\
\text { [43] }\end{array}$ & $\mathrm{N} / \mathrm{S}$ & $\begin{array}{c}\text { ethanolic, } \\
\text { ethanolic: } \\
\text { aqueous and } \\
\text { aqueous extracts } \\
\text { of leaves }\end{array}$ & Mice & $\begin{array}{l}\text { Improvement in blood } \\
\text { glucose profile }\end{array}$ \\
\hline $\begin{array}{l}\text { Antidiabetic efficacy and } \\
\text { hypoglycemic } \\
\text { mechanisms[75] }\end{array}$ & White & $\begin{array}{l}\text { Aqueous extract } \\
\text { of the whole tuber }\end{array}$ & $\begin{array}{l}\text { Streptozotocin } \\
\text { induced- diabetic } \\
\text { rats }\end{array}$ & $\begin{array}{l}\text { Increase in serum insulin } \\
\text { level and reduced fasting } \\
\text { plasma glucose }\end{array}$ \\
\hline $\begin{array}{l}\text { Anti-Inflammatory and } \\
\text { Anticancer activities [48] }\end{array}$ & Purple & $\begin{array}{c}\text { Crude } \\
\text { anthocyanin } \\
\text { extracts }\end{array}$ & $\begin{array}{l}\text { In vitro, cancer } \\
\text { cell lines }\end{array}$ & $\begin{array}{l}\text { Inhibit the growth of } \\
\text { cancer cells and } \\
\text { proinflammatory cytokines }\end{array}$ \\
\hline $\begin{array}{l}\text { Characterization, } \\
\text { antioxidant and antitumor } \\
\text { activities [76] }\end{array}$ & Purple & $\begin{array}{c}\text { Three } \\
\text { polysaccharides } \\
\text { extract }\end{array}$ & Cell line & $\begin{array}{l}\text { Inhibit the growth of } \\
\text { tumour cells }\end{array}$ \\
\hline $\begin{array}{l}\text { Immunomodulatory and } \\
\text { antioxidant effects on } \\
\text { induced murine acquired } \\
\text { immune deficiency } \\
\text { syndrome [59] }\end{array}$ & Purple & $\begin{array}{l}\text { Aqueous and } \\
\text { ethanol extract of } \\
\text { root tubers }\end{array}$ & Mice & $\begin{array}{l}\text { Show potential to improve } \\
\text { immune dysfunction by } \\
\text { modulating antioxidant } \\
\text { defense systems. }\end{array}$ \\
\hline $\begin{array}{l}\text { Effect on apoptosis and } \\
\text { Inflammatory Adipokine } \\
\text { Expression [77] }\end{array}$ & Purple & $\begin{array}{l}\text { Hot water extract } \\
\text { of the leaves }\end{array}$ & 3T3-L1 cell line & $\begin{array}{l}\text { Induced apoptosis and } \\
\text { downregulated } \\
\text { inflammation-associated } \\
\text { genes }\end{array}$ \\
\hline $\begin{array}{l}\text { Antifungal activities of } \\
\text { Anthocyanins from Sweet } \\
\text { Potato [78] }\end{array}$ & Purple & $\begin{array}{l}\text { Anthocyanin } \\
\text { extract with } \\
\text { preservatives }\end{array}$ & In vitro assay & $\begin{array}{l}\text { Enhance } \\
\text { activity }\end{array}$ \\
\hline
\end{tabular}

$N / S$ - not specified in the study

researches on sweet potato have focused on the pharmacological screening of the flour or crude extract of both leaves and the root tubers. Further studies looking at isolation and characterization of bioactive compounds should be an important follow up step to pharmacological screenings in sweet potato.
Finally, the impact of dietary intake of the different cultivars of sweet potato as a whole food on disease indicators such as oxidative stress in humans over an extensive period needs to be evaluated time can be investigated. A positive result can actually encourage consumers 
to embrace sweet potato as a disease preventing food crop especially in areas where it is readily available. Incorporation of the nutritionally rich cultivars of sweet potato into the daily diet might on a long term prevent the incidence of chronic diseases.

\section{CONCLUSION}

Sweet potato is a global food crop that can be explored for its nutritional and medicinal value. This review highlights the important biological activities of sweet potato which are highly influenced by cultivar type. Cultivation of sweet potato genotypes with superior health-promoting and medicinal properties can decrease the need for transgenic modifications. Cultivars with high biological activities can be used to develop high nutraceutical value products or provide the platform for the identification and isolation of certain bioactive constituents which may serve as a starting or model molecule for the production of semi or novel synthetic drugs. Knowledge of the general pharmacological activities of sweet potato and the peculiar bioactivities of the different cultivars will facilitate optimal exploration of the medicinal value of sweet potato. Most of the studies that were reviewed were carried out in vitro, more in vivo studies involving humans, clinical studies should be set up to validate the potential use of sweet potato in combating degenerative diseases. In depth toxicological studies should be carried out to determine the safety of bioactive constituents of sweet potato extract. This will strengthen the interest of research in exploring the medicinal worth of sweet potato beyond its food resource value.

\section{DECLARATIONS}

\section{Acknowledgement}

The authors would like to thank Northwest University, Mafikeng, South Africa for contributing to the success of this work.

\section{Conflict of Interest}

No conflict of interest associated with this work.

\section{Contribution of Authors}

The authors declare that this work was done by the authors named in this article and all liabilities pertaining to claims relating to the content of this article will be borne by them.

\section{Open Access}

This is an Open Access article that uses a funding model which does not charge readers or their institutions for access and distributed under the terms of the Creative Commons Attribution License (http://creativecommons.org/licenses/by 14.0) and the Budapest Open Access Initiative (http://www.budapestopenaccessinitiative.org/rea d), which permit unrestricted use, distribution, and reproduction in any medium, provided the original work is properly credited.

\section{REFERENCES}

1. Senanayake $S A$, Ranaweera KKDS, Gunaratne A, Bamunuarachchi $A$. Comparative analysis of nutritional quality of five different cultivars of sweet potatoes (Ipomoea batatas (L) Lam) in Sri Lanka. Food Sci Nutr 2013; 1: 284-291.

2. Ferris RSB, Wanda K, Tuyisenge J. Munkankubana $D$, Kagiraneza $B$, Ngaboyisonga $C$, Gatarayiha $C$, Uwantege C, Kanyange C, Butare L. Sweet potato Subsector market survey Rwanda, ATDT-CIAT/ISAR/IITAFOODNET and PEARL-Project, Rwanda, 2002.

3. Islam S. Nutritional and Medicinal Qualities of Sweet potato Tops and Leaves. Cooperative Extension Service, University of Arkansas 2014.

4. Grace $M H$, Yousef GG, Gustafson SJ, Truong VD, Yencho GC, Lila MA. Phytochemical changes in phenolics, anthocyanins, ascorbic acid, and carotenoids associated with sweet potato storage and impacts on bioactive properties. Food Chem 2014; 145: 717-724.

5. Konczak-Islam I, Yoshimoto M, Hou DX, Terahara N, Yamakawa O. Potential chemopreventive properties of anthocyanin-rich aqueous extracts from in vitro produced tissue of sweet potato (Ipomoea batatas L.). J Agric Food Chem 2003; 51: 5916-5922.

6. Flores $G, W u$ SB, Negrin A, Kennelly EJ. Chemical composition and antioxidant activity of seven cultivars of guava (Psidium guajava) fruits. Food Chem 2015; 170: 327-335.

7. Shekhar S, Mishra D, Buragohain, AK, Chakraborty S, Chakraborty, N. Comparative analysis of phytochemicals and nutrient availability in two contrasting cultivars of sweet potato (Ipomoea batatas L.). Food Chem 2015; 173: 957-965.

8. Schronk MJ. The Sweet Potato: An Important Part of Human Health. Department of Horticulture, Texas A and M University, College Station, TX 77843. 2010.

9. Department of Agriculture, Forestry and Fisheries, Republic of South Africa. Sweet potato production retrieved from http://www.nda.agric.za/docs/Brochures/PG_SweetPotat o.pdf. 2011.

10. Hijmans RJ, Huaccho L, Zhang DP. Global distribution of sweet potato. CIP Program Report 1999; 2000: 323329.

Trop J Pharm Res, December 2016; 15(12): 2758 
11. Verma VM. Sweet potato cultivation guide. Kosrae Agricultural Experiment Station 2014. p.14.

12. Laurie SM, Niederwieser JG. The Sweet potato plant. In: Niederwieser JG editor. Guide to sweet potato production in South Africa. ARC-Roodeplaat Vegetable and Ornamental Plant Institute, Pretoria, South Africa; 2004. p. 7-14.

13. Woolfe JA. "Sweet potato: an untapped food resource", Cambridge Univ. Press and the International Potato Center (CIP). Cambridge, UK. 1992.

14. FAO (1990). Production Statistics for 1990. FAO, Rome, Italy.

15. Teow CC, Truong VD, McFeeters RF, Thompson RL, Pecota KV, Yencho GC. Antioxidant activities, phenolic and $\beta$-carotene contents of sweet potato genotypes with varying flesh colors. Food Chem 2007; 103: 829-838.

16. Scalbert A, Johnson IT, Saltmarsh M. Polyphenols: antioxidants and beyond. Am J Clin Nutr 2005; 81: 215S-217S

17. United States Department of Agriculture (USDA), Agricultural Research Service, Nutrient Data Laboratory (2015) USDA National Nutrient Database for Standard Reference, Release 28. (cited 2016 March 11). Available from Internet: http://www.ars.usda.gov/ba/bhnrc/ndl.

18. Hue SM, Chandran S, Boyce AN. Variation of leaf and storage roots morphology on Ipomoea batatas $L$. (Sweet potato) cultivars. Asia pacific symposium on postharvest research. Education and extension 2010; 943: 73-79.

19. Bester C, Louw JH. Sweet potato breeding in South Africa. Vegetable and Ornamental Plant Institute. J S Afr Soc Hort Sci 1992; 2: 22-68.

20. Bester C, Van den Berg AA, du Plooy CP. 'Blesbok' sweet potato. Hort Sci 1991; 26: 1229-1230.

21. Tan SL, Nakatani M. Komaki K. Breeding of sweet potato In: Kang MS, Priyadarshan PM, editors. Breeding major food staples. Blackwell publishing; 2007. p. 333-364.

22. Carpena AL. Important cultivars, varieties, and hybrids. In The sweet potato. Springer Netherlands; 2009. pp 2740.

23. Tumwegamire $S$, Kapinga $R$, Zhang D, Crissman $C$, Agill S. Opportunities for promoting orange-fleshed sweet potato as a mechanism for combat vitamin A-deficiency in sub-saharan Africa. Afr Crop Sci J 2004; 12: 241-252.

24. Kapinga R, Ortiz O, Ndunguru J, Omiat E, Tumwegamire S. Handbook of Sweet potato Integrated Crop Management. Research Outputs and Programs for East Africa (1995-2006). International Potato Center (CIP). 2007.

25. Anthoney Swamy, T, Omwenga, J. Analysis of phytochemical composition of white and purple sweet potato (Ipomoea batatas [L] Lam) root. Indian J Adv Plant Res 2014; 1: 19-22.

26. Lila MA. Anthocyanins and human health: an in vitro investigative approach. J. Biomed Biotechnol 2004; 5 : 306-313.

27. Park SY, Lee SY, Yang JW, Lee JS, Oh SD, Oh S, Lee SM, Lim MH, Park SK, Jang JS et al. Comparative analysis of phytochemicals and polar metabolites from colored sweet potato (Ipomoea batatas L.) tubers. Food Sci Biotechnol 2016; 25: 283-291.

28. Robbins RJ. Phenolic acids in foods: an overview of analytical methodology. J. Agric Food Chem 2003; 51: 2866-2887.

29. Gurmu F, Hussein S, Laing M. The potential of orangefleshed sweet potato to prevent vitamin A deficiency in Africa. Int J Vitam Nutr Res 2014; 84: 65-78.

30. Gripper J. "Sweet Potato." Vegetable Book... Forgotten Natural Remedies. S.I.: Lulu Com; 2013.p. 87-88.

31. Anbuselvi S, Balamurugan T. Phytochemical and antinutrient constituents of cassava and sweet potato. World J Pharm Sci 2014; 3: 1440-1449.

32. Dutta S. Sweet potatoes for diabetes mellitus: $A$ systematic review. Pharmacophore 2015; 6: 60-72.

33. Devasagayam TPA, Tilak JC, Boloor, KK, Sane, KS, Ghaskadbi SS, Lele RD. Free radicals and antioxidants in human health: current status and future prospects. Japi 2004; 52: 4.

34. Florence TM. The role of free radicals in disease. Aust NZJ Agric Food Chem Opthamol 1995; 23: 3-7.

35. Nagai $M$, Tani $M$, Kishimoto $Y$, lizuka $M$, Saita $E$, Toyozaki M, Kondo K. Sweet potato (Ipomoea batatas L.) leaves suppressed oxidation of low density lipoprotein (LDL) in vitro and in human subjects. J Clin Biochem Nutr 2011; 48: 203.

36. Fidrianny I, Ira R, Komar RW. Antioxidant capacities from various leaves extracts of four varieties mangoes using $D P P H, A B T S$ assays and correlation with total phenolic, flavonoid, carotenoid. Int J Pharm Pharm Sci 2013; 5(4): 189-194.

37. Tang Y, Cai W, Xu B. Profiles of phenolics, carotenoids and antioxidative capacities of thermal processed white, yellow, orange and purple sweet potatoes grown in Guilin, China. Food Sci Human Wellness 2015; 4: 123132.

38. Ji $\mathrm{H}$, Zhang $\mathrm{H}, \mathrm{Li} H, \mathrm{Li} Y$. Analysis on the nutrition composition and antioxidant activity of different types of sweet potato cultivars. Food Nutr Sci 2015; 6: 161.

39. Salawu SO, Udi E, Akindahunsi AA, Boligon AA, Athayde ML. Antioxidant potential, phenolic profile and nutrient composition of flesh and peels from Nigerian white and purple skinned sweet potato (Ipomea batatas L.). Asian J Plant Sci Res 2015; 5: 14-23.

40. Ludvik B, Neuffer B, Pacini G. Efficacy of Ipomoea batatas (Caiapo) on diabetes control in type 2 diabetic subjects treated with diet. Diabetes Care. 2004; 27: 436440.

41. Zakir S, Sarwar M, Allen J, Butt MS, Arshad U, Javaid A. Impact of sweet potato cultivars on blood glucose level in diabetic and healthy participants. Int J Agr Biol, 2008; 10: 316-320.

42. Ogunrinola OO, Fajana OO, Olaitan SN, Adu OB, Akinola MO. Anti-diabetic activity of Ipomoea batatas leaves extract: Effects on hepatic enzymes in alloxan-induced diabetic rats. Res J Med Plants 2015; 9: 227-233.

Trop J Pharm Res, December 2016; 15(12): 2759 
43. Pal S, Gautam S, Mishra A, Maurya R, Srivastava AK. Antihyperglycemic and antidyslipidemic potential of Ipomoea batatas leaves in validated diabetic animal models. Int J Pharm Pharm Sci 2015; 7: 176-186.

44. Ludvik B, Hanefeld M, Pacini G. Improved metabolic control by Ipomoea batatas (Caiapo) is associated with increased adiponectin and decreased fibrinogen levels in type 2 diabetic subjects. Diabetes Obes Metab 2008; 10: 586-592.

45. Lindsay RS, Funahashi $T$, Hanson RL, Matsuzawa $Y$, Tanaka S, Tataranni PA, Knowler WC, Krakoff J. Adiponectin and development of type 2 diabetes in the Pima Indian population. The Lancet 2002; 360: 57-58.

46. Zhao R, Li Q, Long L, Li J, Yang R, Gao D. Antidiabetic activity of flavone from Ipomoea batatas leaf in non-insulin dependent diabetic rats. Int $\mathrm{J}$ Food Sci Technol 2007; 42: 80-85.

47. Karna P, Gundala SR, Gupta MV, Shamsi SA, Pace RD, Yates $C$. Polyphenol-rich sweet potato greens extract inhibits proliferation and induces apoptosis in prostate cancer cells in vitro and in vivo. Carcinogenesis 2011; 32: $1872-1880$.

48. Sugata M, Lin CY, Shih YC. Anti-inflammatory and anticancer activities of Taiwanese purple-fleshed sweet potatoes (Ipomoea batatas L. Lam) extracts. BioMed Res Int 2015 .doi.org/10.1155/2015/768093.

49. Wang LS, Stoner GD. Anthocyanins and their role in cancer prevention. Cancer Letters 2008; 269: 281-290.

50. Li PG, Mu TH, Deng L. Anticancer effects of sweet potato protein on human colorectal cancer cells. World $J$ Gastroenterol 2013; 19: 3300.

51. Hermes $D$, Dudek DN, Maria MD, Horta LP, Lima EN, de Fátima $\hat{A}$, Sanches $A C$, Modolo LV. In vivo wound healing and antiulcer properties of white sweet potato (Ipomoea batatas). J adv Res 2013; 4: 411-415.

52. Panda V, Sonkamble M. Anti-ulcer activity of Ipomoea batatas tubers (sweet potato). Funct Food Health Dis 2012; 2: 48-61.

53. Sathish R, Rani M, Natarajan K. Study of ulcer protective effect of Ipomoea batatas (L.) dietary tuberous roots (Sweet Potato). Iranian J Pharmacol Ther 2012; 11: 3639.

54. Steinberg $D$. The $L D L$ modification hypothesis of atherogenesis: an update. J Lipid Res 2009; 50(Suppl): S376-S381.

55. Mazza G. Anthocyanins and heart health. Ann I Super Sanita 2007; 43: 369.

56. Chen CM, Li SC, Liao YY, Liu JF, Shyur LF, Chen PR, Chen CY. In vitro immunomodulatory effect of Ipomoea batatas L. tuber bioactives. The FASEB J 2013; 27(1 Supplement): 862-869.

57. Hanieh H, Gerile C, Narabara K, Gu Z, Abe A, Kondo Y. In vivo immunomodulatory effects of dietary purple sweet potato after immunization in chicken. Animal Sci J 2010; 81:116-121.

58. Chen YC, Chang HS, Lai HM, Jeng ST. Characterization of the wound inducible protein IPOMOELIN from sweet potato. Plant Cell Environ 2005; 28: 251-259.
59. Kim OK, Nam DE, Yoon HG, Baek SJ, Jun W, Lee J. Immunomodulatory and antioxidant effects of purple sweet potato extract in LP-BM5 murine leukemia virusinduced murine acquired immune deficiency syndrome. J Med Food 2015; 18: 882-889.

60. Chang WH, Chen CM, Hu SP, Kan NW, Chiu CC, Liu JF. Effect of purple sweet potato leaves consumption on the modulation of the immune response in basketball players during the training period. Asia Pac J Clin Nutr 2007; 16: 609-615.

61. Adsul VB, Khatiwora E, Torane R, Deshpande NR. Antimicrobial activities of Ipomoea carnea leaves. $J$ Natural Product and Plant Resources 2012; 2 (5): 597600.

62. Mbaeyi-Nwaoha IE, Emejulu VN. Evaluation of phytochemical composition and antimicrobial activity of sweet potato (Ipomoea batatas) leaf. Pakistan J Nutr 2013; 12: 575.

63. Yoshimoto $M$, Kido $M$, Kurata $R$, Kobayashi $T$ Antibacterial activity of sweet potato (Ipomoea batatas L.) fibre on food hygienic bacteria. The Bulletin of the Institute of Minami-Kyushu Regional. Science, Kagoshima Women's Junior College 2011; 27: 5-17.

64. Shen XL, Wu JM, Chen Y, Zhao G. Antimicrobial and physical properties of sweet potato starch films incorporated with potassium sorbate or chitosan. Food Hydrocoll 2010; 24: 285-290.

65. Kang H, Kwak Y, Koppula S. Protective effect of purple sweet potato (Ipomoea batatas Linn, Convolvulaceae) on neuroinflammatory responses in lipopolysaccharidestimulated microglial cells. Trop J Pharm Res 2014; 13(8): 1257-1263.

66. Wang YJ, Zheng YL, Lu J, Chen GQ, Wang XH, Feng J, Ruan J, Sun X, Li CX, Sun QJ. Purple sweet potato color suppresses lipopolysaccharide-induced acute inflammatory response in mouse brain. Neurochem Int 2010; 56(3): 424-430.

67. Osime EO, Ediale GE, Omoti CE, Famodu AA. Effect of sweet potato leaf (Ipomoea batatas) extract on some haematological parameters using rabbits. $J$ Med Biomed Res 2008; 7: 12-15.

68. Montejo JF, Mondonedo JAB, Lee MGA, Ples MB, Vitor RJS. Hematological effects of Ipomoea batatas (camote) and Phyllanthus niruri (sampa-sampalukan) from Philippines in the ICR mice (Mus musculus). Asian Pac J Trop Biomed 2015; 5: 29-33.

69. Kennedy G, Burlingame B. Analysis of food composition data on rice from a plant genetic resources perspective. Food Chem 2003; 80: 589-596.

70. Legua P, Melgarejo P, Abdelmajid H, Martinez JJ, Martinez $R$, Ilham $H$, Hafida $H$, Hernandez F. Total phenols and antioxidant capacity in 10 moroccan pomegranate varieties J Food Sci 2012; 71: 115-120.

71. Tehranifar A, Mehdi Z, Zahra N, Behnam E, Mohamad $R V$. Investigation of physico-chemical properties and antioxidant activity of twenty Iranian pomegranate (Punica granatum L.) cultivars. Sci Hort 2010; 126: 180 185.

Trop J Pharm Res, December 2016; 15(12): 2760 
72. Harrison HF, Peterson JK, Snook ME, Bohac JR, Jackson DM. Quantity and potential biological activity of caffeic acid in sweet potato [Ipomoea batatas (L.) Lam.] storage root periderm. J Agric Food Chem 2003; 51 : 2943-2948.

73. Kim JM, Park SJ, Lee CS, Ren C, Kim SS, Shin M. Functional properties of different Korean sweet potato varieties. Food Sci Biotechnol 2011; 20: 1501-1507.

74. Park WS, Bae JY, Kim HJ, Kim SH, Lee HS, Kwak SS, Ahn MJ. Antiulcer and antiadipogenic acitities of carotenoid and anthocyanin extracts from color-fleshed sweet potato. Planta Medica 2014; 80, 20 DOI: 10.1055/s-0034-1382715.

75. Niwa A, Tajiri T, Higashino, H. Ipomoea batatas and Agarics blazei ameliorate diabetic disorders with therapeutic antioxidant potential in streptozotocininduced diabetic rats. J clin Biochem Nutr 2011; 48 . 194-202.
76. Wu Q, Qu H, Jia J, Kuang C, Wen Y, Yan H, Gui Z. Characterization, antioxidant and antitumor activities of polysaccharides from purple sweet potato. Carbohydr polym 2015; 132: 31-40.

77. Lee SL, Chin TY, Tu SC, WangYJ, Hsu YT, Kao MC, Wu YC. Purple sweet potato leaf extract induces apoptosis and reduces inflammatory adipokine expression in 3T3L1 differentiated adipocytes. Evid Based Complement Alternat Med 2015; doi.org/10.1155/2015/126302.

78. Wen $H$, Kang J, Li D, Wen W, Yang F, Hu H, Liu C. Antifungal activities of anthocyanins from purple sweet potato in the presence of food preservatives. Food Sci Biotechnol 2016; 25(1): 165-171.

79. Mendonça-Filho RR. Bioactive phytocompounds: New approaches in the phytosciences. In: I. Ahmad, F. Aqil, M. Owais, editors. Modern phytomedicine: Turning medicinal plants into drugs; 2006. p. 1-25. 